\title{
Identifying cost-minimizing strategies for guaranteeing target dairy income over feed cost via use of the Livestock Gross Margin dairy insurance program
}

\author{
M. Valvekar, ${ }^{*}$ V. E. Cabrera, ${ }^{* 1}$ and B. W. Gould $†$ \\ ${ }^{*}$ Department of Dairy Science, and \\ †Department of Agricultural and Applied Economics, University of Wisconsin, Madison 53706
}

\begin{abstract}
Milk and feed price volatility are the major source of dairy farm risk. Since August 2008 a new federally reinsured insurance program has been available to many US dairy farmers to help minimize the negative effects of adverse price movements. This insurance program is referred to as Livestock Gross Margin Insurance for Dairy Cattle. Given the flexibility in contract design, the dairy farmer has to make 3 critical decisions when purchasing this insurance: 1) the percentage of monthly milk production to be covered, 3 ) declared feed equivalents used to produce this milk, and 3) the level of gross margin not covered by insurance (i.e., deductible). The objective of this analysis was to provide an optimal strategy of how a dairy farmer could incorporate this insurance program to help manage the variability in net farm income. In this analysis we assumed that a risk-neutral dairy farmer wants to design an insurance contract such that a target guaranteed income over feed cost is obtained at least cost. We undertook this analysis for a representative Wisconsin dairy farm (herd size: 120 cows) producing 8,873 $\mathrm{kg}(19,545 \mathrm{lb})$ of milk/cow per year. Wisconsin statistical data indicates that dairy farms of similar size must require an income over feed cost of at least $\$ 110 / \mathrm{Mg}(\$ 5 / \mathrm{cwt})$ of milk to be profitable during the coverage period. Therefore, using data for the July 2009 insurance contract to insure $\$ 110 / \mathrm{Mg}$ of milk, the least cost contract was found to have a premium of $\$ 1.22 / \mathrm{Mg}(\$ 0.055 / \mathrm{cwt})$ of milk produced insuring approximately $52 \%$ of the production with variable monthly production covered during the period of September 2009 to June 2010. This premium represented $1.10 \%$ of the desired IOFC. We compared the above optimal strategy with an alternative nonoptimal strategy, defined as a contract insuring the same proportion of milk as the optimal $(52 \%)$ but with a constant amount insured across all contract months.
\end{abstract}

Received October 12, 2009.

Accepted April 5, 2010.

${ }^{1}$ Corresponding author: vcabrera@wisc.edu
The premium was found to be almost twice the level obtained under the cost-minimizing solution representing $1.9 \%$ of the insured amount. Our model identifies the lowest cost insurance contract for a desired target guaranteed income over feed cost.

Key words: price risk, risk management, dairy revenue insurance, price volatility

\section{INTRODUCTION}

The value of milk represents more than $90 \%$ of a typical dairy farm's income (ERS, 2009). In addition, feed costs can represent more than $40 \%$ of a dairy farm's variable costs (Ishler et al., 2009). With relatively stable production, uncertainty in milk and feed prices represent a major source of business risk in any dairy farm. There is no doubt that the volatility of milk prices has increased since the mid 1980s (Gould et al., 2008). In response to this increased volatility, several viable futures and options markets have evolved since the mid 1990s. Currently, there are futures markets at the Chicago Mercantile Exchange (CME) for class III milk, class IV milk, butter, dry whey, and nonfat dry milk. Starting in May 2010, there will be additional contracts for skim milk powder, an important traded dairy commodity. In addition, there are options markets for class III milk, class IV milk, butter, and nonfat dry milk. For an overview of the use of dairy-based futures and options, refer to Jesse and Cropp (2009).

Dairy farmers have the ability to either be directly involved with the above markets or use forward or minimum price contracts offered by their processing plant to manage their output price risk. With the passage of the Food, Conservation and Energy Act of 2008 (i.e., 2008 Farm Bill), private firms can now offer forward and minimum price contracts to their farm patrons. Despite the availability of these financial instruments, only a small percentage of US dairy farmers currently undertake any type of milk price risk management (ERS, 2009).

Dairy farmers now have the ability to move beyond managing just output price variability in that they can 
Table 1. Description of variables used in the Livestock Gross Margin Insurance for Dairy (LGM-Dairy) cost minimization model

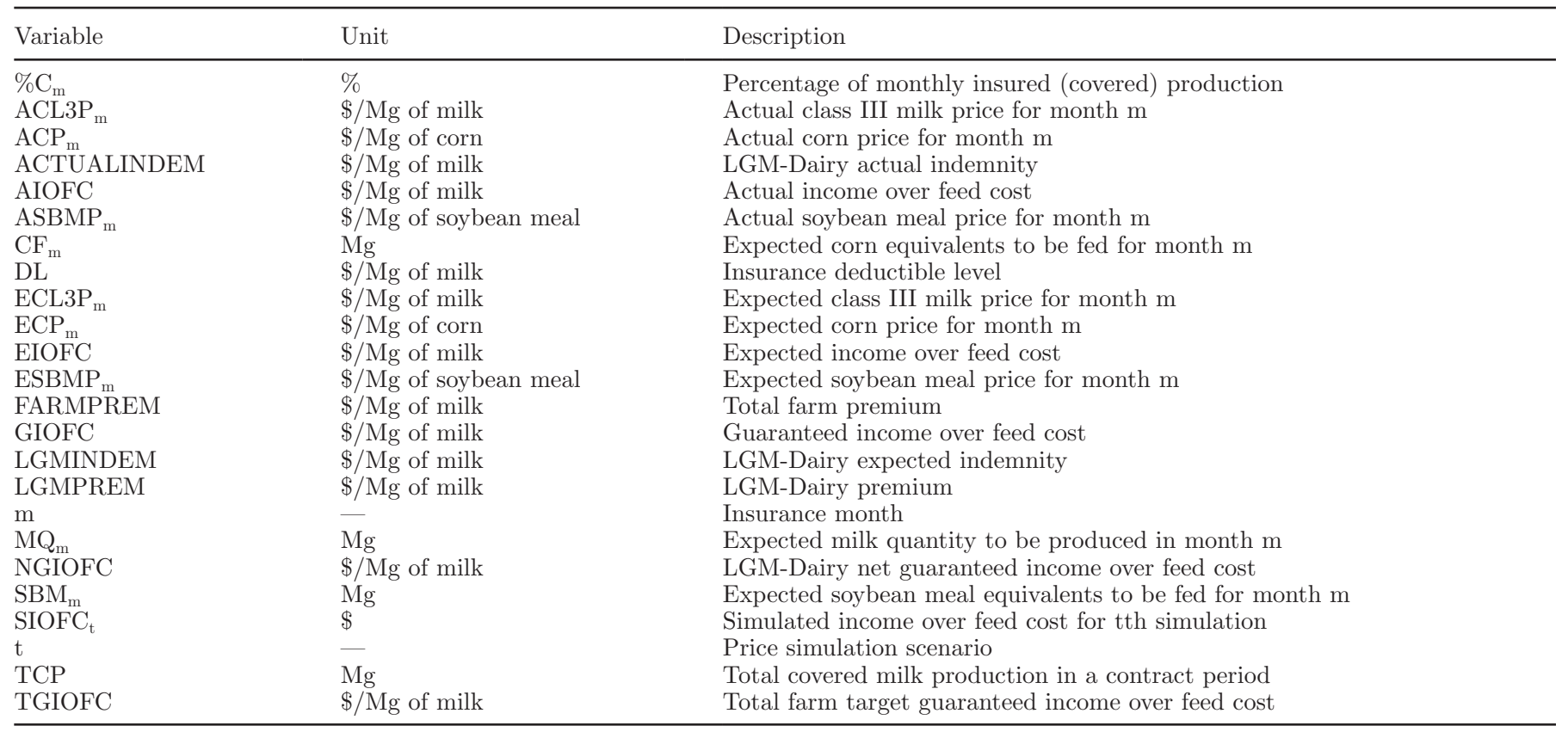

manage their income over feed cost (IOFC) risk via the use of a single insurance program. Specifically, since August 2008, dairy farmers have had a risk protection tool referred to as Livestock Gross Margin Insurance for Dairy Cattle (LGM-Dairy) to control the variability in their IOFC. It can be considered analogous to the use of a bundled option risk management strategy where class III put options establish a milk price floor and feed-based call options are used to set a feed cost ceiling. Such a strategy reduces the downside IOFC risk but allows for possibly higher values.

The ability of LGM-Dairy to reduce the downside IOFC risk obviously comes at a cost. The degree of desired protection and dairy farmer risk preferences will determine how this program is integrated into a farm's marketing program. Under the assumption that the dairy farmer is risk neutral, the dairy farmer may have as a marketing goal the establishment of a target IOFC for the entire dairy farm's production at the least cost. The objective of this study was to describe and demonstrate an algorithm to identify optimal strategies for guaranteeing a desired IOFC for all farm milk via use of the LGM-Dairy insurance contract.

\section{MATERIALS AND METHODS}

\section{General Description of the LGM-Dairy Program}

In 2007, the Federal Crop Insurance Corporation of the USDA (Washington, DC) endorsed the LGM-Dairy program and allowed the first policies to be purchased at the end of August 2008 (RMA, 2009a,d). Under this program, dairy farmers can purchase insurance to protect against unanticipated decreases in expected milk revenue over imputed purchased feed costs. An indemnity at the end of the insurance period is the difference, if positive, between the expected IOFC (EIOFC) determined at insurance sign-up and actual IOFC (AIOFC) determined at contract maturity. Both EIOFC and AIOFC are estimated using class III, corn, and soybean meal (SBM) futures contracts settlement prices at the CME during LGM-Dairy contract initiation and futures contract expiration, respectively. To participate in LGM-Dairy, the dairy farm needs to be located in one of the 36 states that are LGM-Dairy eligible as listed in the 2010 LGM-Dairy Commodity Exchange Endorsement (RMA, 2009b). The LGM-Dairy insurance can be purchased any month of the year and can cover up to 10 mo of EIOFC. The following is a mathematical description of the LGM-Dairy insurance and the optimization problem objective of this study. Table 1 includes a summary of all the variables used in the analyses.

\section{Mathematical Description of LGM-Dairy}

Because no premium subsidies are available, the dairy farmer's LGM-Dairy premium is set equal to the longterm expected (average) indemnity the dairy farmer would receive given the contract specification. The USDA Risk Management Agency (Washington, DC) estimates each farmer's actuarially fair insurance pre- 
mium defined such that the dairy farm premium equals the expected indemnities via use of 5,000 simulated indemnities. These simulated indemnities are obtained using random draws of the 30 correlated commodity prices for the $10 \mathrm{mo}$ of insurance contract (10 class III, 10 corn, and $10 \mathrm{SBM}$ prices) and the specific contract design under consideration. These random draws are obtained from assumed lognormal distributions as outlined in the LGM-Dairy program policy (RMA, 2009c).

As defined by the RMA (2009c), the average of simulated indemnities (plus a 3\% reserve load or reasonable insurance reserve) obtained under each scenario determines the dairy farmer's insurance premium. This relationship can be represented as

$$
\text { LGMPREM }=\frac{1.03 \times \text { LGMINDEM }}{\mathrm{TCP}},
$$

where LGMPREM is the per-unit premium $(\$ / \mathrm{Mg}$ of milk), TCP is the total covered milk production in the contract period, and LGMINDEM is the expected (average) of the simulated indemnities:

$$
\text { LGMINDEM }=\frac{\sum_{t=1}^{5,000} \operatorname{Max}\left[\left(\mathrm{GIOFC}-\mathrm{SIOFC}_{\mathrm{t}}\right), 0\right]}{5,000},
$$

where SIOFC is the simulated IOFC determined over the 5,000 price scenarios and t represents the th price simulation scenario. The GIOFC is guaranteed IOFC determined at contract sign-up and is calculated using the EIOFC, a deductible level (DL) and covered production $\left(\mathrm{TCP}_{\mathrm{m}}=\% \mathrm{C}_{\mathrm{m}} \times \mathrm{MQ}_{\mathrm{m}}\right.$ where $\mathrm{MQ}_{\mathrm{m}}$ is the monthly quantity of milk expected to be produced) for the $m$ th month:

$\mathrm{GIOFC}=\sum_{m=1}^{10}\left[\% \mathrm{C}_{\mathrm{m}} \times\left(\begin{array}{l}\mathrm{MQ}_{\mathrm{m}} \times \mathrm{ECL}_{\mathrm{m}}-\mathrm{CF}_{\mathrm{m}} \times \mathrm{ECP}_{\mathrm{m}} \\ -\mathrm{SBM}_{\mathrm{m}} \times \mathrm{ESBMP}_{\mathrm{m}}-\mathrm{DL} \times \mathrm{MQ}_{\mathrm{m}}\end{array}\right)\right.$,

where $\% \mathrm{C}_{\mathrm{m}}$ is the percent of monthly production elected to be insured (0 to 100\%); ECL3 $\mathrm{P}_{\mathrm{m}}$ is the expected class III price obtained from the price discovery period (the price discovery period ends on the last business Friday of each insurance purchase month and starts the previous Wednesday); $\mathrm{CF}_{\mathrm{m}}$ is the total corn equivalent amount expected to be fed to obtain $\mathrm{MQ}_{\mathrm{m}}$; $\mathrm{ECP}_{\mathrm{m}}$ is the expected corn price obtained from the price discovery period; $\mathrm{SBM}_{\mathrm{m}}$ is the amount of $\mathrm{SBM}$ equivalent expected to be fed to obtain $\mathrm{MQ}_{\mathrm{m}}$; and $\mathrm{ESBMP}_{\mathrm{m}}$ is the expected SBM price obtained from the price discovery period for the month $\mathrm{m}$. Insurance premiums are farm specific because they depend on the desired contract design.

Given the above, we define net GIOFC (NGIOFC) via the following:

$$
\text { NGIOFC }=(\text { GIOFC } / \text { TCP })-\text { LGMPREM. }
$$

Unlike class III milk futures, which are traded every month, only 5 contracts are traded for corn grain and only 8 are traded for SBM each year. For insurance month with no corn or SBM futures contracts that expire, the expected corn grain price is the weighted average of the daily settlement prices of the surrounding months during the expected price measurement period (RMA, 2009a). For class III, corn, and SBM, the actual price measurement periods are the $3 \mathrm{~d}$ before the last trading day of the associated futures contract. The weights are based on the distance between the desired month and futures contract month actually used and are proportional to the number of months until the futures contract expires.

Similar to any insurance policy, the dairy farmer identifies the portion of the GIOFC not to be insured. Allowable deductibles range from $\$ 0$ to $33.1 / \mathrm{Mg}$ of milk in increments of $\$ 2.2 / \mathrm{Mg}$ of milk ( $\$ 0$ to $1.5 /$ cwt of milk in increments of $\$ 0.10 / \mathrm{cwt}$ ). Higher deductibles imply lower insurance premiums because this, by definition, reduces potential insurance liability given lower indemnity probabilities and, if there are indemnities, the amounts are lower.

At the end of the insurance period, the actual insurance indemnity is the difference, if positive, between the GIOFC and the AIOFC, where the AIOFC is the IOFC estimated at the end of each LGM-Dairy contract month as the contract matures. The indemnity is then calculated as follows:

$$
\mathrm{ACTUALINDEM}=\max (\mathrm{GIOFC}-\mathrm{AIOFC}, 0),[5]
$$

where

$$
\mathrm{AIOFC}=\sum_{m=1}^{10}\left[\% \mathrm{C}_{\mathrm{m}} \times\left(\begin{array}{l}
\mathrm{MQ}_{\mathrm{m}} \times \mathrm{ACL}_{\mathrm{m}}-\mathrm{CF}_{\mathrm{m}} \times \mathrm{ACP}_{\mathrm{m}} \\
-\mathrm{SBM}_{\mathrm{m}} \times \mathrm{ASBMP}_{\mathrm{m}}-\mathrm{DL} \times \mathrm{MQ}_{\mathrm{m}}
\end{array}\right)\right],
$$

where $\mathrm{ACL} \mathrm{P}_{\mathrm{m}}$ is the actual class III milk price calculated as the simple average of the daily settlement prices of the CME class III milk futures contract during the actual price measurement period for month $\mathrm{m}$, and $\mathrm{ACP}_{\mathrm{m}}$ is actual corn price calculated as the simple average of the daily settlement prices for the CME corn futures contract for the month $\mathrm{m}$ during the actual 
price measurement period. Similar to expected prices, for months with no corn or SBM futures contracts, the actual price is the weighted average of the immediately surrounding months' simple average of the daily settlement prices during the actual price measurement period.

\section{Formulation of the Optimization Problem}

For the present study we assumed that a risk-neutral dairy farmer wants to identify an LGM-Dairy insurance program such that a target farm guaranteed IOFC (TGIOFC) is returned at the least farm premium (FARMPREM) cost. It should be remembered that one of the decision variables of the dairy farmer is the percentage of milk to be covered each month $\left(\% \mathrm{C}_{\mathrm{m}}\right)$. This implies that, depending on the market conditions at sign-up, the minimum TGIOFC may be obtained with only a portion of the farm's production being insured. As specified in the LGM-Dairy policy, the dairy farmer cannot insure more than $10,866 \mathrm{Mg}(240,000$ cwt) of milk during any 10-mo coverage period. We can represent the minimization problem of the dairy farmer via the following:

$$
\begin{aligned}
& \text { Optimal LGM-Dairy contract = } \\
& \underset{\% \mathrm{C}_{\mathrm{m}}, \mathrm{DL}, \mathrm{CF}_{\mathrm{m}}, \mathrm{SBM}_{\mathrm{m}}}{\mathrm{Min}} \text { (FARMPREM), }
\end{aligned}
$$

subject to

$$
\begin{gathered}
\text { TGIOFC } \geq\left(\frac{\text { GIOFC }}{\sum_{m=1}^{10} \mathrm{MQ}_{\mathrm{m}}}\right)-\text { FARMPREM and } \\
\mathrm{TCP} \leq 10,886 \mathrm{Mg} \text { of milk, }
\end{gathered}
$$

where

$$
\text { FARMPREM }=1.03 \times\left(\frac{\text { LGMINDEM }}{\sum_{m=1}^{10} \mathrm{MQ}_{\mathrm{m}}}\right) .
$$

As developed above, the possible decision variables are the percentage of each month's production to be covered $\left(\% \mathrm{C}_{\mathrm{m}}\right)$, the deductible level $(\mathrm{DL})$, and feed amounts $\left(\mathrm{CF}_{\mathrm{m}}, \mathrm{SBM}_{\mathrm{m}}\right)$. To reduce the degree of nonlinearity of this model, we fixed the DL and used program default corn and SBM equivalent feed amounts per unit of milk produced.
The model is nonlinear because the actuarially fair premium (FARMPREM in Equations 7, 8, and 10) is conditional on program design (Cabrera et al., 2009). We therefore used the generalized reduced gradient method of nonlinear programming to solve this optimization problem. This method of solution allows for nonlinear constraints and arbitrary bounds on the variables in the optimization process. To ensure that we identify the global minimum, we set every insurance month coverage percentage to nonzero starting values (Ragsdale, 2004).

\section{Parameters, Assumptions, and Scenarios Used in the Optimization Model}

We assumed a representative Wisconsin dairy farm (herd size: 120 cows) producing 8,873 kg $(19,545 \mathrm{lb})$ of milk/cow per year. We used insurance premium data associated with the July 2009 insurance contract. This implies that the possible coverage months are from September 2009 to June 2010. To account for differences in per-cow productivity across months, we used monthspecific per-cow milk production using Wisconsin State summary data between 1999 and 2008 (NASS, 2009).

We used default corn and SBM equivalent feed rates per unit of milk produced according to the program policy (280 $\mathrm{kg}$ of corn equivalents and $40 \mathrm{~kg}$ of SBM equivalents $/ \mathrm{Mg}$ of milk produced). Milk sales, corn equivalents to be fed, and SBM equivalents to be fed for the July 2009 contract are shown in Table 2.

Table 3 provides a summary of the expected prices and price volatilities, which are used by the USDA Risk 8] Management Agency to generate the random draws used in premium determination. The price volatilities are time dependent and calculated such that the nearest months are less volatile than the later months. Average annual volatilities are deannualized by multiplying the estimated volatilities by the square root of the time (d) remaining until futures contract settlement (RMA, 2008). These volatilities represent 1 standard deviation movement in the futures price of the underlying commodity over the time remaining for the expiration of the option contract (Mullaney, 2009). It is evident from Table 3 that there is an increasing trend in volatilities over time for class III milk, corn, and SBM prices. For example, the average deannualized volatility until the expiration of contract for September 2009 class III milk is $9 \%$ at LGM-Dairy contract sign-up and the June 2010 class III contract has a volatility of $21 \%$. This implies that the risk faced under the June 2010 class III futures contract is greater than that for the September 2009 class III futures at the July 2009 LGM-Dairy signup period. 
Table 2. Milk sales and default feed amounts used for a representative 120-cow Wisconsin dairy farm producing 8,873 $\mathrm{kg}$ of milk/cow per year for July 2009 Livestock Gross Margin Insurance for Dairy (LGMDairy) contract ${ }^{1}$

\begin{tabular}{lrrc}
\hline Coverage month & MQ $(\mathrm{kg})$ & CF $(\mathrm{kg})$ & $\mathrm{SBM}(\mathrm{kg})$ \\
\hline September 2009 & 86,129 & 24,116 & 3,445 \\
October 2009 & 87,780 & 24,578 & 3,511 \\
November 2009 & 84,773 & 23,737 & 3,391 \\
December 2009 & 88,959 & 24,909 & 3,558 \\
January 2010 & 89,224 & 24,983 & 3,569 \\
February 2010 & 82,562 & 23,118 & 3,303 \\
March 2010 & 91,287 & 25,561 & 3,652 \\
April 2010 & 89,254 & 24,991 & 3,570 \\
May 2010 & 93,469 & 26,171 & 3,739 \\
June 2010 & 89,843 & 25,156 & 3,594 \\
Total & 883,280 & 247,319 & 35,331 \\
\hline
\end{tabular}

${ }^{1} \mathrm{MQ}=$ the total milk production expected to be sold; $\mathrm{CF}=$ the total corn equivalent amount expected to be fed to obtain total milk production; SBM = the total soybean meal equivalent amount expected to be fed to obtain total milk production.

Given the expected prices, price volatilities, and price correlation matrices, 5,000 random draws of the 30 prices for the 10-mo July 2009 contract were obtained directly from the USDA Risk Management Agency. Table 4 provides a summary of the SIOFC with a $100 \%$ covered production. From these data, we see that the monthly IOFC distributions are also right skewed as evidenced by the mean being greater than the median and mode for most coverage months. This is not surprising given that prices are assumed lognormally distributed (RMA, 2009c).
The last column of Table 4 shows the proportion of SIOFC lower than the EIOFC for each individual month. Because of higher expected prices, increased variance, and more skewed distributions for the distant months, the proportion of the SIOFC being lower than the EIOFC increases. This implies that the overall premium will increase when insuring those months, all other things being equal. In terms of our optimization model, the data presented in Tables 3 and 4 imply a trade-off associated with choosing to cover more distant months. That is, the expected returns are higher

Table 3. Expected prices and price volatility for months covered under the July 2009 Livestock Gross Margin Insurance for Dairy (LGM-Dairy) period

\begin{tabular}{lccc}
\hline Item & Class III milk & Corn & SBM $^{1}$ \\
\hline Expected price $(\$ / \mathrm{Mg})$ & & & \\
September 2009 & 267 & 130 & 354 \\
October 2009 & 280 & 131 & 330 \\
November 2009 & 297 & 133 & 326 \\
December 2009 & 305 & 134 & 323 \\
January 2010 & 312 & 135 & 318 \\
February 2010 & 314 & 137 & 317 \\
March 2010 & 323 & 139 & 316 \\
April 2010 & 332 & 141 & 314 \\
May 2010 & 332 & 143 & 312 \\
June 2010 & 345 & 144 & 312 \\
Price volatility ${ }^{2}(\%)$ & & & \\
September 2009 & 9 & - & 14 \\
October 2009 & 11 & - & 17 \\
November 2009 & 13 & 21 & 21 \\
December 2009 & 14 & - & 22 \\
January 2010 & 16 & - & - \\
February 2010 & 17 & - & 26 \\
March 2010 & 18 & - & 28 \\
April 2010 & 19 & 30 & - \\
May 2010 & 20 & & \\
\hline
\end{tabular}

${ }^{1} \mathrm{SBM}=$ soybean meal.

${ }^{2}$ Price volatilities are available only for months for which there are contracts (RMA, 2009c). 
Table 4. Summary statistics for 5,000 simulated monthly income over feed costs (SIOFC) with $100 \%$ production covered for a representative 120-cow Wisconsin dairy farm producing 8,873 kg of milk/cow per year for July 2009 Livestock Gross Margin Insurance for Dairy (LGM-Dairy)

\begin{tabular}{lcccccc}
\hline Coverage month & Mean $(\$)$ & Median $(\$)$ & Mode $(\$)$ & SD $(\$)$ & Skewness & $\begin{array}{r}\text { SIOFC }< \\
\text { EIOFC }^{1}(\%)\end{array}$ \\
\hline September 2009 & 18,650 & 18,569 & 20,658 & 2,127 & 0.26 & 8.02 \\
October 2009 & 20,207 & 20,065 & 19,048 & 2,757 & 0.32 & 14.68 \\
November 2009 & 20,956 & 20,740 & 20,954 & 3,335 & 0.36 & 20.32 \\
December 2009 & 22,679 & 22,434 & 22,638 & 3,890 & 0.38 & 22.86 \\
January 2010 & 23,271 & 22,952 & 26,552 & 4,520 & 0.45 & 26.84 \\
February 2010 & 21,736 & 21,386 & 17,947 & 4,485 & 0.49 & 28.48 \\
March 2010 & 24,820 & 24,357 & 20,416 & 5,406 & 0.52 & 30.28 \\
April 2010 & 24,994 & 24,521 & 25,729 & 5,718 & 0.54 & 32.46 \\
May 2010 & 26,180 & 25,639 & 20,001 & 6,322 & 0.55 & 33.02 \\
June 2010 & 26,224 & 25,603 & 27,745 & 6,589 & 0.59 & 35.04 \\
\hline
\end{tabular}

${ }^{1}$ Proportion of SIOFC lower than expected income over feed cost (EIOFC) when having a LGM-Dairy contract with a $\$ 33.1 / \mathrm{Mg}$ of milk deductible.

for these months, but with higher skewed simulated returns. These higher expected returns are insured at a higher cost.

We also used for this contract the highest level of deductible allowed by the LGM-Dairy insurance of $\$ 33.1 / \mathrm{Mg}$ (\$1.5/cwt) of milk because we have found in previous analyses that, under normal market conditions, premiums are substantially reduced with higher deductible with relatively smaller gross income impacts (Cabrera et al., 2009). By assuming $\$ 33.1 / \mathrm{Mg}$ of milk, the optimal solution is found faster because fewer iterations are required to reach the optimal solution.

Analyses were done for a range of possible TGIOFC scenarios believed to be reasonable between $\$ 66$ and $220 / \mathrm{Mg}$ ( $\$ 3$ and 10/cwt) of milk. As a reference, we examined a range of IOFC for a sample of 500 Wisconsin dairy farms of similar size participating in the Agriculture Financial Advisor (AgFA, 2009) program managed by the Center for Dairy Profitability (www. cdp.wisc.edu/AgFa.htm) at the University of Wisconsin-Madison over the 2004 to 2008 period. These data indicated that dairy farms of similar size require an IOFC of at least $\$ 110.23 / \mathrm{Mg}(\$ 5 / \mathrm{cwt})$ of milk.

\section{Analyses Performed}

We solved the optimization problem over a range of possible farm-level TGIOFC to examine how the optimal insurance program could change with different targets. For each solution scenario, we report the optimal milk coverage for each month (i.e., $\% \mathrm{C}_{\mathrm{m}}$ ), LGMPREM, FARMPREM, and NGIOFC. We further analyzed the results to compare these optimal solutions with an alternative nonoptimal strategy, where the same amount of TCP is covered as in the optimal solution but it is insured evenly across the months encompassed by the July 2009 contract. The model was solved using the Premium solver Excel (Microsoft Corp., Redmond, WA) add-on software system (version 5.0, Frontline Systems, Incline Village, NV).

\section{RESULTS AND DISCUSSION}

\section{Effect of Alternative Target Income on Optimal Insurance Design}

Table 5 shows the optimal coverage percentages (i.e., $\left.\% \mathrm{C}_{\mathrm{m}}\right)$ under alternative TGIOFC levels. As a reference, a contract assuming 100\% coverage production every month with a $\$ 33.1 / \mathrm{Mg}$ of milk deductible would generate a FARMPREM value of $\$ 3,756(\$ 4.25 / \mathrm{Mg}$ of milk or $\$ 0.193 /$ cwt of milk) and a TGIOFC of $\$ 196,747$ ( $\$ 222.7 / \mathrm{Mg}$ of milk or $\$ 10.10 /$ cwt of milk).

If a dairy farmer's TGIOFC is $\$ 110.23 / \mathrm{Mg}$ ( $\$ 5 / \mathrm{cwt})$ of milk, the least cost contract to secure this TGIOFC would be to insure all the production during the first 4 mo and less than $100 \%$ for the remaining months. The contract implies a FARMPREM of $\$ 1.22 / \mathrm{Mg}(\$ 0.055 /$ cwt) of milk and an LGMPREM value of $\$ 2.34 / \mathrm{Mg}$ $(\$ 0.106 / \mathrm{cwt})$ of milk and would insure approximately $52 \%$ of the dairy farm's production over the September 2009 to June 2010 period. The total insurance cost would be $\$ 1,075$.

As discussed earlier, a TGIOFC of $\$ 110.23 / \mathrm{Mg}$ of milk is considered the lower boundary of TGIOFC calculated for comparative Wisconsin farms. For a TGIOFC of $\$ 132.28 / \mathrm{Mg}(\$ 6 / \mathrm{cwt})$ of milk, the optimal contract would insure approximately $62 \%$ of the farm's production over the insurance period at a FARMPREM of $\$ 1.68 / \mathrm{Mg}(\$ 0.076 / \mathrm{cwt})$ of milk and an LGMPREM of $\$ 2.73 / \mathrm{Mg}(\$ 0.124 / \mathrm{cwt})$ of milk. The total insurance cost at this TGIOFC would be $\$ 1,486$.

Although we used a hypothetical Wisconsin dairy farm for the analysis, the framework presented here is applicable to any dairy farm regardless of size and 
Table 5. Optimal percentage of production insured under alternative target guaranteed income over feed cost (TGIOFC) for a representative 120-cow Wisconsin dairy farm producing $8,873 \mathrm{~kg}$ of milk/cow per year for July 2009 Livestock Gross Margin Insurance for Dairy (LGM-Dairy) contract

\begin{tabular}{|c|c|c|c|c|c|c|c|c|c|}
\hline Item & \multicolumn{9}{|c|}{ TGIOFC ( $\$ / \mathrm{Mg}$ of milk) } \\
\hline \multicolumn{10}{|l|}{ Optimal monthly coverage (\%) } \\
\hline October 2009 & 100 & 100 & 100 & 100 & 100 & 100 & 100 & 100 & 100 \\
\hline November 2009 & 60 & 100 & 100 & 100 & 100 & 100 & 100 & 100 & 100 \\
\hline December 2009 & 27 & 63 & 100 & 100 & 100 & 100 & 100 & 100 & 100 \\
\hline March 2010 & 12 & 13 & 26 & 13 & 25 & 52 & 100 & 100 & 100 \\
\hline April 2010 & 0 & 4 & 8 & 8 & 11 & 27 & 42 & 100 & 100 \\
\hline May 2010 & 10 & 15 & 15 & 30 & 33 & 38 & 59 & 91 & 100 \\
\hline June 2010 & 16 & 25 & 44 & 60 & 78 & 94 & 100 & 100 & 100 \\
\hline Optimal total coverage (\%) & 33 & 43 & 52 & 62 & 72 & 81 & 90 & 99 & 100 \\
\hline \multicolumn{10}{|l|}{ Optimal program costs and guarantee } \\
\hline FARMPREM $^{1}(\$ / \mathrm{Mg}$ of milk) & 0.53 & 0.84 & 1.22 & 1.68 & 2.20 & 2.79 & 3.45 & 4.17 & 4.25 \\
\hline
\end{tabular}

${ }^{1}$ Total farm premium (i.e., the total insurance cost divided by the total megagrams of milk produced on the farm).

${ }^{2}$ LGM-Dairy premium per megagram of milk.

${ }^{3}$ LGM-Dairy net guaranteed income over feed cost.

location. We assumed a fixed amount of feed per unit of milk produced over the insurance period, but the model can easily be extended to allow for the use of different amounts of feed per unit of milk across months (University of Wisconsin, 2010).

As shown in Table 5, nearby contract months are first selected and in higher proportion. This result may seem surprising given lower expected prices for these months compared with more distant months. This implies that the overall premium will increase when insuring these months. Therefore, the optimal solution first chooses the nearby contract months for $100 \%$ coverage and later the more distant months are insured.

\section{Comparison of Optimal LGM-Dairy Contract Designs and Nonoptimal Strategies}

Tables 5 and 6 compare the program performances for the optimal and nonoptimal strategies where the nonoptimal strategy covers the same percentage of total 10-mo production but this coverage is spread evenly across months. As expected, FARMPREM as a percentage of the TGIOFC is lower under the least-cost strategy. For example, to insure a TGIOFC of $\$ 110.23 / \mathrm{Mg}$ ( $\$ 5 /$ cwt) of milk, the optimal insurance cost is $\$ 1,075$, FARMPREM is $1.10 \%$ of TGIOFC, and optimal coverage is $52 \%$ of the production. The nonoptimal strategy with the same coverage of $52 \%$ for all 10 mo would cost $\$ 1,968$ and would be $1.91 \%$ of the TGIOFC. In other words, the optimal strategy would cost $\$ 893(\$ 0.99 / \mathrm{Mg}$ of milk or $0.04 /$ cwt of milk) less than the nonoptimal strategy. This difference, however, decreases when the TGIOFC is set higher. At a TGIOFC of $\$ 220.46 / \mathrm{Mg}$ of milk, the optimal FARMPREM is $\$ 3,686(\$ 4.17 / \mathrm{Mg}$ of milk or $\$ 0.189 /$ cwt of milk), whereas FARMPREM for the nonoptimal solution is $\$ 3,722(\$ 4.21 / \mathrm{Mg}$ of milk or $\$ 0.191 /$ cwt of milk), only about $\$ 36$ lower.

As expected, to have a higher TGIOFC, higher milk quantities are required to be insured. The optimal solution becomes closer to the nonoptimal strategies at higher TGIOFC. A higher differential between an optimal and nonoptimal solution occurs when TGIOFC is lower. On the other hand, a contract is less valuable if the protection level is too low. A farmer's risk management strategy would need to find an optimal balance between the TGIOFC and the opportunity of having a lower differential premium price. For instance, Table 6 shows that the FARMPREM when insuring $33 \%$ of the production (having a low TGIOFC) is $\$ 0.53 / \mathrm{Mg}$ of milk for the optimal and $\$ 1.40 / \mathrm{Mg}$ of milk for the nonoptimal solution, or 2.64 times lower for the optimal solution. However, the FARMPREM when insuring $90 \%$ of the production (having a high TGIOFC) is $\$ 3.45 / \mathrm{Mg}$ of milk for the optimal and $\$ 3.83 / \mathrm{Mg}$ of milk for the nonoptimal solution, or only 1.11 times lower for the optimal solution.

Several extensions to our model should be undertaken to increase its applicability as a risk management tool 
Table 6. Optimal and nonoptimal strategy for a representative 120-cow Wisconsin dairy farm producing $8,873 \mathrm{~kg}$ of milk/cow per year for July 2009 Livestock Gross Margin Insurance for Dairy (LGM-Dairy) contract ${ }^{1}$

\begin{tabular}{|c|c|c|c|c|c|}
\hline \multirow[b]{2}{*}{$\begin{array}{l}\text { Total production } \\
\text { covered }(\%)\end{array}$} & \multicolumn{2}{|c|}{ Optimal strategy } & \multicolumn{2}{|c|}{ Nonoptimal strategy $y^{2,3}$} & \multirow{2}{*}{$\begin{array}{c}\text { Nonoptimal } \\
\text { FARMPREM/ optima } \\
\text { FARMPREM }\end{array}$} \\
\hline & $\begin{array}{c}\text { TGIOFC } \\
\text { (\$/Mg of milk) }\end{array}$ & $\begin{array}{l}\text { FARMPREM } \\
\text { (\$/Mg of milk) }\end{array}$ & $\begin{array}{c}\text { TGIOFC } \\
\text { (\$/Mg of milk) }\end{array}$ & $\begin{array}{l}\text { FARMPREM } \\
\text { (\$/Mg of milk) }\end{array}$ & \\
\hline 33 & 66.14 & 0.53 & 73.51 & 1.40 & 2.64 \\
\hline 43 & 88.19 & 0.84 & 95.83 & 1.83 & 2.17 \\
\hline 52 & 110.23 & 1.22 & 116.83 & 2.23 & 1.83 \\
\hline 62 & 132.28 & 1.68 & 138.04 & 2.64 & 1.57 \\
\hline 90 & 198.42 & 3.45 & 200.74 & 3.83 & 1.11 \\
\hline 99 & 220.46 & 4.17 & 220.74 & 4.21 & 1.01 \\
\hline
\end{tabular}

${ }^{1}$ TGIOFC $=$ target guaranteed income over feed cost; FARMPREM = total farm premium (i.e., the total insurance cost divided by the total megagrams of milk produced on the farm).

${ }^{2}$ The same proportion of total milk production covered as the optimal solution but evenly distributed every insurance month.

${ }^{3}$ FARMPREM as a percentage of TGIOFC is $1.91 \%$ and the probability of indemnity is $21.46 \%$ for all levels of total production covered.

for US dairy farm operators. Given the availability of the use of traditional options-based risk management strategies, it is important to extend the above optimization model to include the use of dairy and grain bundled options strategies as an alternative to achieve the desired TGIOFC. Thus, in an extended model, the dairy farmer would be able to perform a portfolio analysis to choose the use of LGM-Dairy or a bundled options strategy, or a combination of the two.

\section{CONCLUSIONS}

Dairy farmers interested in using the LGM-Dairy insurance as a price risk management tool could save premium costs by designing an optimized LGM-Dairy contract. This study demonstrates that for similar levels of coverage (i.e., proportion of total milk production insured), there are substantial differences in insurance premium cost depending upon the distribution of the production insured over the 10-mo LGM-Dairy contract. For a dairy farmer insuring about half of the farm production, this premium could be $80 \%$ lower for the optimal contract than for the nonoptimal contract. The model described in this study is a simplified nonlinear programming model that can be used by a dairy farmer to identify an LGM-Dairy contract design that will insure a TGIOFC at minimum premium cost.

\section{REFERENCES}

Agriculture Financial Advisor (AgFA). 2009. University of Wisconsin Center for Dairy Profitability financial benchmarks. http://cdp. wisc.edu/AgFA.htm Accessed Aug. 14, 2009.

Cabrera, V. E., B. W. Gould, and M. Valvekar. 2009. Livestock gross margin insurance for dairy cattle: An analysis of program performance and cost under alternative policy configurations. Agricultural and Applied Economics Association 2009 Annual Meeting, Milwaukee, WI. http://ageconsearch.umn.edu/ bitstream/49262/2/610926.pdf Accessed Oct. 5, 2009.
Economic Research Service (ERS). 2009. Agricultural resource management survey (2007). USDA Economic Research Service. http://www.ers.usda.gov/data/arms Accessed Sept. 10, 2009.

Gould, B. W., P. D. Mitchell, and V. E. Cabrera. 2008. USDA's gross margin insurance program for dairy: What is it and can it be used for risk management. Marketing and policy briefing paper. Department of Agricultural and Applied Economics, University of Wisconsin-Madison. http://future.aae.wisc.edu/pubs/pubs/ show/339 Accessed Jul. 17, 2009.

Ishler, V., E. Cowan, and T. Beck. 2009. Track your income over feed costs. Hoard's Dairyman 10:490.

Jesse, E., and R. Cropp. 2009. Futures and options trading in milk and dairy products: A guidebook for dairy producers. Publication no. A3732. University of Wisconsin Extension, Madison, WI

Mullaney, M. 2009. The Complete Guide to Option Strategies: Advanced and Basic Strategies on Stocks, ETFs, Indexes and Stock Index Futures. John Wiley and Sons Inc., Hoboken, NJ.

National Agricultural Statistics Service (NASS). 2009. Wisconsin dairy statistics 1999-2008. http://www.nass.usda.gov/Statistics_ by_State/Wisconsin/index.asp Accessed Aug. 21, 2009.

Ragsdale, C. 2004. Spreadsheet Modeling Decision Analysis. A Practical Introduction to Management Science. 4th ed. Thompson South Western, Mason. OH

Risk Management Agency (RMA). 2008. Livestock gross margin insurance policy: Rating methodology. http://future.aae.wisc.edu/ lgm-dairy/rma_material/rating_methods.pdf Accessed Mar. 29, 2010.

Risk Management Agency (RMA). 2009a. Livestock gross margin insurance policy. http://www.rma.usda.gov/policies/2010/ lgm/10lgmdairypolicy.pdf Accessed Aug. 14, 2009.

Risk Management Agency (RMA). 2009b. Livestock gross margin for dairy cattle insurance policy: Frequently asked questions. USDA Risk Management Agency. http://www.rma.usda.gov/ policies/2010/lgm/10lgmdairyq\&a.pdf Accessed Aug. 14, 2009.

Risk Management Agency (RMA). 2009c. Livestock gross margin insurance policy: Step by step instructions to calculate premium. USDA Risk Management Agency. http://www.rma.usda.gov/ policies/2010/lgm/10lgmdairypremcalc.pdf Accessed Aug. 14, 2009.

Risk Management Agency (RMA). 2009d. Livestock gross margin for dairy cattle insurance policy: Underwritten rules. USDA Risk Management Agency. http://www.rma.usda.gov/policies/2010/ lgm/10lgmdairyundrules.pdf Accessed Aug. 14, 2009.

University of Wisconsin. 2010. Understanding dairy markets: LGMDairy-Least-Cost. http://future.aae.wisc.edu/lgm_dairy.html\#2 Accessed Jan. 20, 2010. 